\title{
Ujian Nasional (UN): \\ Harapan, Tantangan, dan Peluang
}

\author{
Gunadi H. Sulistyo
}

\begin{abstract}
The National Examination (NE) has been conducted for several times nationwide. However, public debates always emerge over the importance of NE prior to the annual excecution of the examination. The government's policy to raise the passing standard under the pretext of improving the quality of the national education has commonly triggered a heated controversy. This paper discusses the NE from the perspectives of expectations, challenges and opportunities. It attempts to provide an objective picture as to the need to hold NE. As such, it puts the attempts to improve the quality of the national education through NE in a proportionately wider perspective.
\end{abstract}

KEYWORDS national examination, national education, quality of national education

Peluncuran Keputusan Mendiknas Nomor 153/U/2003 Tanggal 14 Oktober 2003 tentang Ujian Akhir Nasional (selanjutnya disingkat UN) untuk tahun pelajaran 2003/2004 sebagai kebijakan pemerintah yang diberlakukan secara nasional telah mengundang berbagai reaksi negatif dari berbagai kalangan. Reaksi negatif yang ada pada umumnya memunculkan sikap pesimis. Husnawati (2004), misalnya, melontarkan beberapa pandangan negatifnya. Dengan UN 2004, siswa akan belajar seperti mesin dalam rangka pencapaian target yang ditentukan saja, sementara itu kemampuan yang lain terabaikan. Selain itu, penentuan passing grade dapat merupakan stressor yang berpotensi menghantui siswa. Juga, dikatakannya bahwa soal-soal UN berpeluang menghambat perkembangan multiple intelligence siswa. Selanjutnya, Santoso (2004) juga melontarkan pesimismenya sebagai berikut. Butir-butir soal UN hanya berdimensi akademis pedagogis saja dan tidak berorientasi membebaskan siswa dari ketidakpekaan terhadap lingkungannya. Juga, dikatakannya bahwa matauji dan butir-butir UN tidak mengembangkan logika, inovasi, dan daya tahan emosi siswa. Selain komentar-komentar tersebut, pembahasan yang bersifat akademis pun pernah dilakukan. Dalam suatu seminar yang diselenggarakan di Universitas Negeri Jakarta pada tanggal 11 April 2004, nada negatif juga muncul, antara lain disebutkan bahwa UN memerkosa hak-hak siswa. Bahkan, nada pesimis juga bergaung dari gedung DPR. Dalam dengar pendapat antara Komisi VI yang membidangi 
masalah pendidikan dengan Departemen Pendidikan Nasional (Depdiknas) mengemuka pesimisme yang senada dengan pandangan yang disebut sebelumnya. Bahkan, ada desakan kuat agar UN dihapus di tahun ajaran berikutnya. Ada beberapa alasan yang menjadi dasar penghapusan tersebut, yaitu standar passing grade 4.01 dinilai memberatkan siswa; siswa belum memiliki kesiapan yang minim; kualitas guru yang belum memadai; anggaran penyelenggaraan terlalu besar; dan pengujian dilakukan pada aspek kognitif siswa saja; bahkan ada pandangan bahwa UN melanggar UU Sisdiknas No. 20 tahun 2003 (Jawa Pos 5 Mei 2004).

Sementara itu, pandangan yang mendukung pelaksanaan UN juga bergaung dari berbagai kalangan. Musthofa (2004) menyatakan bahwa UN perlu didukung karena beberapa alasan berikut. UN merupakan bentuk idealisasi bangsa yang akan mampu mengikis pelecehan rendahnya mutu pendidikan nasional di tingkat global. UN dapat berperan sebagai motivator belajar siswa dan mengembangkan semangat kompetisi siswa. UN akan menggugah semangat dan motivasi guru untuk mengajar lebih baik lagi. Selain itu, penentuan tiga matauji UN, yaitu Bahasa Inggris, Bahasa Indonesia, dan Matematika dipandang strategis dalam menjawab tantangan global. Senada dengan pendapat Musthofa tersebut, Prameswari (2004) berpandangan bahwa UN akan mampu menepis kesenjangan antarsekolah dan antardaerah apabila dilaksanakan dengan konsekuen. dan menjadi langkah awal untuk membenahi dunia pendidikan agar menjadi lebih baik lagi.

Dari berbagai reaksi yang muncul tersebut, secara umum dapat dikatakan bahwa meskipun mendapatkan dukungan, pemerintah, dalam hal ini Departemen Pendidikan Nasional menuai kritik yang cukup pedas dengan kebijakan meluncurkan keputusan tentang UN pada tahun 2003/2004. Meskipun demikian, pemerintah tetap bersikukuh pada keputusannya, yaitu tetap melaksanakan UN tahun 2003/2004. Itu terbukti dari penyelenggaraan UN yang dimulai pada bulan Mei yang baru lalu.

UN bukanlah "barang" baru dalam wacana nasional. Sebenarnya telah ada pengalaman pelaksanaan UN tahun lalu. Sebagai catatan: UN telah mulai diberlakukan sejak tahun ajaran 2002/2003. Namun, peluncuran Keputusan Mendiknas Nomor 153/U/2003 Tanggal 14 Oktober 2003 ini nampaknya memicu reaksi yang semarak. Dua faktor berikut dapat menjelaskan keadaan ini. Faktor pertama adalah adanya kenaikan standar batas minimal kelulusan dari 3,1 poin menjadi 4,1 poin, dan kemudian untuk UN tahun 2006 dinaikkan menjadi 4,25. Kenaikan standar batas minimal kelulusan ini mengundang reaksi yang beragam. Bagi sekolah yang secara akademik "mapan" dan telah memiliki kesiapan untuk mengantarkan siswanya menghadapi UN, kenaikan standar ini bukanlah sesuatu yang terlalu dirisaukan; bahkan mungkin sekolah-sekolah tersebut beranggapan bahwa standar kelulusan 4,25 adalah sesuatu yang "kecil". Akan tetapi, bagi sekolah-sekolah lain yang belum "siap", masalah kenaikan standar ini dapat merupakan "beban moral" yang amat berat untuk ditanggungnya. Jangankan untuk mencapai 4,0, untuk 
memenuhi standar 3,0 saja, bagi mereka masih merupakan perjuangan berat tersendiri.

Faktor kedua adalah pemerintah terkesan tidak sensitif terhadap keadaan sekolah yang sesungguhnya sehingga kebijakan pemerintah ini terkesan tergesa-gesa. Faktor dominan yang terkait dengan keadaan sekolah yang pada umumnya masih memprihatinkan adalah belum memadainya kondisi atau fasilitas pemelajaran sekolah. Keadaan lain adalah keberadaan sumber daya guru maupun sumber pustaka yang ada belum sepenuhnya mencukupi kebutuhan baik ditinjau dari sudut kuantitas maupun kualitas. Masalah lain sebagai dampak dua keadaan tersebut adalah belum memadainya mutu proses dan kegiatan pemelajaran yang diselenggarakan (Direktur Jenderal Pendidikan Dasar dan Menengah 2004:2; Kebijakan Direktorat Pendidikan Lanjutan Pertama 2004:2). Memang, telah dilakukan berbagai upaya untuk menjembatani kesenjangan tersebut melalui berbagai kebijakan, misalnya Wajib Belajar 9 Tahun dengan berbagai kegiatan di dalamnya. Meskipun begitu, upaya tersebut masih belum berjalan mulus, apalagi setelah terjadi krisis moneter yang berkepanjangan sejak 1997. Keadaan ini memaksa pencapaian target pencanangan pelaksanaan Wajib Belajar 9 tahun (Direktorat Pendidikan Lanjutan Pertama 2004:2) meleset.

Di sisi lain, kebijakan pemerintah yang tetap menyelenggarakan UN memiliki alasan kuat. Direktur Jenderal Pendidikan Dasar dan Menengah (2004:2) menyatakan bahwa UN adalah bagian dari upaya untuk memperbaiki mutu pendidikan nasional yang hingga kini dipandang masih buram. Dinyatakan pula bahwa dalam kurikulum, sistem pendidikan ujian perlu diadakan untuk mengukur proses pencapaian standar yang ditentukan. Ujian merupakan bentuk pertanggungjawaban. Selain itu, ujian adalah bagian dari sistem yang dapat mendorong proses pengajaran guru dan pemelajaran siswa. Ujian memiliki fungsi korektif yang berdampak pada kegiatan mengajar guru dan kegiatan belajar siswa.

Alasan yang dikemukakan tersebut terkesan normatif. Namun demikian, sebenarnya alasan tersebut dapat dikatakan sebagai salah satu bentuk penjabaran konsep pendidikan dalam implementasinya. Ujian memiliki peranan yang penting dalam pendidikan meskipun banyak yang belum memahaminya dengan benar (Athanasou dan Lamprianou 2002:1). Sebagai lembaga yang bertanggung jawab atas mutu pendidikan nasional, pemerintah melalui Departemen Pendidikan Nasional beserta segenap jajaran di bawahnya memiliki kewajiban untuk senantiasa mengupayakan berbagai cara mencerdaskan kehidupan bangsa sesuai Undang Undang Dasar 1945. Oleh karena itu, alasan di atas pun sebenarnya dapat didudukkan pada porsinya sehingga dapat dipahami dan diterima dengan baik oleh semua pihak.

Uraian di atas menyiratkan adanya pertentangan pendapat antara Departemen Pendidikan Nasional sebagai instrumen pemerintah yang mendapatkan amanat untuk menjalankan pembangunan pendidikan nasional dan masyarakat yang sebenarnya merupakan sasaran pembangunan 
pendidikan. Dalam kehidupan masyarakat demokrasi, pertentangan pendapat dalam masalah UN tersebut adalah hal yang wajar dan justru diperlukan. Pertentangan dalam wacana semacam ini dapat dikatakan sebagai salah satu bentuk dinamika masyarakat demokratis. Masyarakat demokratis adalah masyarakat yang ditandai dengan ciri "punya suara yang berhak disuarakan dan didengar". Selama ada aksi yang kemudian ditanggapi reaksi dengan itikad membangun (constructive remarks), dinamika demokratis semacam ini akan merupakan kendali (kontrol) yang sehat agar semua pihak dapat saling mendengar, memahami, dan berbuat untuk kebajikan bersama. Bukannya suatu bentuk "pengototan" untuk menang sendiri, apalagi mencari-cari kesalahan pihak lain. Sistem pengujian nasional akan dapat diselenggarakan dengan berhasil guna, yaitu dalam rangka meningkatkan mutu pendidikan nasional, apabila penyelenggaraannya didasarkan pada kajian-kajian yang mendalam dan sistematis, dan perencanaannya dilakukan secara konseptual akademik dengan ide yang inovatif.

Tulisan ini dikembangkan dalam upaya untuk menyajikan suatu bentuk pemikiran yang diharapkan dapat memberikan masukan pada penyelenggaraan UN pada masa mendatang. Untuk mencapai tujuan penulisan ini, tulisan ini dibagi menjadi empat bagian. Bagian I menyajikan latar belakang dan tujuan penulisan. Bagian II membahas Ujian Akhir Nasional (UN) dengan fokus pada perkembangan sistem pengujian nasional, kajian yuridis dan teoritis. Bagian III membahas keadaan dan masalah pendidikan nasional yang ada pada saat ini. Bagian IV memaparkan beberapa hal yang perlu dilakukan ke depan terkait dengan UN.

\section{Sistem Pengujian Nasional: Perspektif Perkembangan} SEJARAHNYA

UN sebagai suatu kebijakan pemerintah bukanlah sesuatu yang muncul begitu saja dari Departemen Pendidikan Nasional. Sepanjang sejarah kehidupan Negara Kesatuan Republik Indonesia, pemerintah telah memberlakukan beberapa kebijakan yang diarahkan pada upaya-upaya untuk menjaga mutu pendidikan. Direktur Jenderal Pendidikan Dasar dan Menengah (2004:2) menyatakan bahwa sejak tahun 1945 setidaknya telah ada tiga periode yang telah dilalui oleh pemerintah dalam upaya menjaga mutu pendidikan melalui berbagai bentuk kebijakan sistem ujian. Ketiga periode itu adalah periode sistem ujian negara, periode ujian sekolah penuh, dan periode evaluasi belajar tahap akhir nasional. Ketiga periode tersebut muncul dalam dinamika pencarian format dengan pengujian yang akuntabel dan sahih.

Periode sistem ujian negara berlangsung hampir selama dua dasawarsa, yaitu sejak tahun 1945 hingga tahun 1964. Pada periode ini, semua siswa menempuh ujian akhir untuk menyelesaikan jenjang pendidikannya dalam bentuk ujian yang disebut ujian negara. Sesuai dengan namanya, yaitu ujian negara, semua piranti ujian dipersiapkan oleh negara. Semua mata pelajaran yang akan diujikan dan semua soal yang ditanyakan berdasarkan mata 
pelajaran yang diujikan ditentukan dan disiapkan oleh negara. Demikian juga dalam penyelenggaraannya, peran negara sangat dominan dan ketat. Singkatnya, pada periode ini suasana sentralisasi pelaksanaan ujian sangat terasa.

Ada kelemahan dan keunggulan dengan penyelenggaraan sistem ujian negara tersebut. Kelemahannya sekaligus merupakan keunggulannya. Oleh karena kendali pemerintah yang sangat ketat, sekolah hampir tidak memiliki kewenangan apalagi campur tangan untuk menentukan kelulusan siswa mereka. Selain itu, kuantitas siswa yang tersaring lolos ujian pada umumnya dapat dikatakan kecil. Namun demikian, mereka yang berhasil lolos ujian negara pada umumnya memiliki kualitas yang dapat dipertanggungjawabkan. Kualitas kelulusan dengan model ujian negara dapat dikatakan tinggi. Tingginya mutu lulusan model ujian negara ini menyebabkan tidak diperlukannya seleksi terhadap siswa agar dapat mengikuti jenjang pendidikan berikutnya.

Namun sistem ujian negara ini dengan segala kelebihan dan kekurangan tersebut dianggap tidak adil karena dipandang tidak memperhatikan kondisi daerah yang memiliki keragaman penyelenggaraan pendidikan. Oleh karena itu, sistem ini kemudian diganti dengan yang lain, yaitu sistem ujian sekolah penuh.

Periode ujian sekolah penuh kemudian menggantikan sistem ujian negara. Sistem ini berlangsung hampir dua dasawarsa, yaitu mulai 1965 hingga 1982. Tidak seperti periode ujian negara yang lebih sentralistis, praktik penyelenggaraan ujian pada periode ujian sekolah sepenuhnya dikendalikan oleh sekolah. Sekolah diberi wewenang penuh untuk mengembangkan piranti ujian dan melaksanakannya. Sekolah juga diberi wewenang untuk menentukan kelulusan Akan tetapi, kewenangan penuh yang diberikan kepada sekolah tidak otomatis diikuti dengan naiknya mutu lulusan secara kualitatif. Secara kuantitatif, memang kelulusannya dapat dikatakan amat memuaskan karena semua siswa lolos ujian akhir. Akan tetapi, pada periode ini terjadi kemerosotan mutu lulusan. Mutu lulusan ujian sekolah penuh menjadi rendah.

Dari segi kuantitas, sistem ujian sekolah memang unggul. Akan tetapi, sistem ini lemah dari segi kualitas lulusannya. Rendahnya mutu lulusan pada sistem ujian sekolah mengundang berbagal kritikan pedas. Ada desakan agar sistem ini dikembalikan kepada sistem ujian negara seperti sistem yang pertama dengan alasan mendongkrak kualitas lulusan.

Pada periode berikutnya, diperkenalkan sistem baru, yaitu sistem Evaluasi Belajar Tahap Akhir Nasional yang dikenal dengan akronim EBTANAS. Sistem EBTANAS berlangsung selama dua dasawarsa, terhitung mulai 1982 hingga tahun 2002. Pada tataran konsep, sistem EBTANAS merupakan gabungan dua sistem ujian yang pernah berlaku sebelumnya, yaitu sistem ujian negara dan sistem ujian sekolah. Kombinasi ini tercermin pada tata cara penilaian yang memperhatikan hasil nilai ujian sekolah dan ujian negara. Diharapkan bahwa 
sistem ini dapat mengoreksi kelemahan pada sistem pengujian yang pernah diberlakukan sebelumnya. Namun kenyataannya, sekali lagi sistem ini juga mengulangi kelemahan yang terjadi pada sistem ujian sekolah penuh. Secara kualitas, mutu lulusan dengan sistem EBTANAS pun dipandang rendah. Disinyalir terjadi pendongkrakan (mark up) nilai siswa yang mestinya rendah menjadi lulus. Ada pandangan yang menyatakan bahwa guru berpeluang mendongkrak nilai siswa karena ujian praktik dan teori digabungkan untuk penentuan nilai akhir siswa (Winoto 2004)

Tahun 2002, EBTANAS diganti dengan sistem Ujian Akhir Nasional atau disingkat UN. Sistem inilah yang hingga kini berlangsung dan yang akhirakhir ini menimbulkan kontroversi yang meluas dalam masyarakat. Apabila diamati, perkembangan sistem ujian nasional sebenamya bertumpu pada upaya peningkatan mutu keluaran hasil pendidikan. Hingga saat ini, pencarian pemerintah atas sistem yang benar-benar dapat menjamin mutu pendidikan melalui sistem pengujian belum berakhir. Pemerintah masih mencari bentuk yang dapat dipertanggungjawabkan, baik secara teoretis konseptual, yuridis formal, maupun sosial. Ini wajar, apalagi dinamika masyarakat dan perkembangan IPTEK berlangsung pesat. Ketika satu permasalahan dapat teratasi, tetapi belum sempat menghasilkan pemecahan yang memuaskan, muncul masalah baru lain yang juga memerlukan perhatian pemecahannya. Tampaknya hal ini juga dihadapi dalam sejarah sistem pengujian nasional. Oleh karena itu, diperlukan pemikiran-pemikiran inovatif dan konseptual yang dikaji dan dikembangkan terus menerus.

\section{Dasar Pemikiran Ujian Nasional (UN)}

Dalam pernyataannya, Direktur Jenderal Pendidikan Dasar dan Menengah (2004:2) mengatakan bahwa UN adalah salah satu upaya pembenahan yang dilakukan Departemen Pendidikan Nasional untuk meningkatkan mutu pendidikan nasional. Ini dilakukan dengan memasang standar nilai minimal yang harus diraih oleh siswa. Dengan mencanangkan nilai minimal sebagai batas kelulusan, diharapkan bahwa ini tidak hanya merupakan tantangan bagi siswa saja, tetapi juga merupakan washback effect yang positif bagi semua pihak, terutama guru dan orang tua. Guru diharapkan dapat menjalankan fungsi pengajaran dengan lebih bersungguh-sungguh sehingga dapat mengantarkan siswa dalam kegiatan pemelajaran.

Demikian juga orang tua, mereka diharapkan akan lebih memperhatikan kesejahteraan dan kebutuhan pemelajaran anak mereka. Mereka diharapkan akan dapat lebih mengawasi dan mendorong anak-anak mereka dalam belajar. Keterlibatan orang tua dalam hal tersebut mengandung maksud bahwa tugas mendidik itu tidak hanya merupakan monopoli sekolah sebagai lembaga formal, tetapi masyarakat pun diharapkan berpartisipasi aktif dalam penyelenggaraan pendidikan anak meskipun dalam bentuk dan tanggung jawab yang berbeda. 
Menurut Keputusan Menteri Pendidikan Nasionai Republik Indonesia Nomor 114/U/2001 tentang Penilaian Hasil Belajar Secara Nasional, UN sebagai salah satu bentuk sarana untuk menilai hasil belajar siswa diselenggarakan dengan pertimbangan antara lain sebagai berikut. Pertama, penilaian tingkat nasional yang diselenggarakan secara sistematis dan berkala perlu dilaksanakan guna memantau, mengendalikan, dan meningkatkan mutu pendidikan dasar dan menengah secara nasional. Kedua, penilaian merupakan cara untuk mengetahui apakah siswa telah belajar sesuai dengan yang diharapkan. Ketiga, setiap warga negara berhak mendapatkan penilaian atas hasil belajarnya yang diperoleh melalui satuan pendidikan.

Sementara itu, menurut Keputusan Menteri Pendidikan Nasional Republik Indonesia Nomor 153/U / 2003 Tanggal 14 Oktober 2003 tentang Ujian Akhir Nasional Tahun Pelajaran 2003/2004, pertimbangan penyelenggaraan UN, antara lain adalah sebagai berikut " "... untuk mengetahui hasil belajar peserta didik dan untuk memperoleh keterangan mengenai mutu pendidikan ..."' pada berbagai jenis dan jenjang pendidikan. Selain itu, penyelenggaraan UN sebagai sarana penjamin "'adanya standar mutu pendidikan yang terukur secara nasional, juga didasarkan atas pertimbangan 'untuk menjaga akuntabilitas pelaksanaan manajemen berbasis sekolah ...".

\section{TUJUAN DAN FUNGSI UN}

Keputusan Menteri Pendidikan Nasional Republik Indonesia Nomor 114/ U/2001 tentang Penilaian Hasil Belajar Secara Nasional menyatakan bahwa penilaian hasil belajar secara nasional, yang antara lain mencakup UN (pasal 3 ayat 1) bertujuan untuk "mengukur pencapaian hasil belajar peserta didik dan mengetahui mutu pendidikan". Sementara itu, fungsinya adalah sebagai

(a) alat pengawasan dan pengendalian mutu pendidikan; (b) bahan pertimbangan dalam penentuan tamat belajar peserta didik pada setiap jenis, jalur, dan jenjang pendidikan; (c) bahan pertimbangan dalam penerimaan peserta didik pada setiap jenis, jalur, dan jenjang pendidikan; dan (d) umpan balik perbaikan program pemelajaran.

Keputusan Menteri Pendidikan Nasional Republik Indonesia Nomor 153/U/2003 Tanggal 14 Oktober 2003 tentang Ujian Akhir Nasional Tahun Pelajaran 2003/2004 bertujuan Nasional untuk

(a) mengukur pencapaian hasil belajar peserta didik; (b) mengukur mutu pendidikan di tingkat nasional, provinsi, kabupaten/kota, dan sekolah/madrasah; (c) mempertanggungjawabkan penyelenggaraan pendidikan secara nasional, provinsi, kabupaten/kota, dan sekolah/madrasah kepada masyarakat. Adapun fungsi UN adalah sebagai (a) alat pengendali mutu pendidikan secara nasional; (b) pendorong peningkatan mutu pendidikan; (c) bahan dalam menentukan kelulusan peserta didik; dan (d) bahan pertimbangan dalam seleksi penerimaan peserta didik baru pada jenjang pendidikan yang lebih tinggi. 
Berdasarkan uraian tentang latar belakang, tujuan dan fungsi ujian nasional tersebut di atas dapat dikatakan bahwa UN pada dasarnya adalah salah satu cara yang digunakan untuk penggalian informasi tentang kualitas pendidikan nasional. Penggalian informasi ini dilakukan dengan menggunakan seperangkat ujian dan dengan menggunakan siswa sebagai sumber data informasi tersebut. Informasi tentang mutu ini diharapkan merupakan cerminan bagaimana manajemen berbasis sekolah itu diselenggarakan di tiap-tiap sekolah. Akan tetapi, tujuan dan fungsi UN yang telah dirumuskan tersebut tidak semuanya dipahami atau diketahui secara umum. Dalam pengertian apakah semua tujuan dan fungsi yang dicanangkan benar-benar direalisasikan oleh Pemerintah. Satu hal yang paling menyentuh masyarakat terkait dengan UN adalah tujuan "mengukur pencapaian hasil belajar peserta didik" dan fungsi "bahan pertimbangan dalam penentuan tamat belajar peserta didik pada setiap jenis, jalur, dan jenjang pendidikan". Dalam kedua segi ini, masyarakat merasakan langsung dampak yang muncul sebagai akibat dari keputusan yang diambil dari hasil pengukuran hasil belajar siswa. Bagi khalayak, ini lebih dominan dibandingkan dengan masalah-masalah lain dalam pendidikan yang juga penting untuk dikritik misalnya fungsionalitas keberadaan sarana dan prasana, kualitas kegiatan belajar-mengajar di kelas, dan sebagainya.

\section{MeKanisme UN 2003/2004}

Tidak seperti sistem ujian nasional yang berlaku sebelumnya, pada UN 2003/2004 hanya ada tiga mata pelajaran yang dikembangkan dan diujikan serta dinilai dengan standar nasional, yaitu Bahasa Inggris, Bahasa Indonesia, dan Matematika. Mata pelajaran lain diujikan secara lokal. Selain itu, penentuan kelulusan adalah minimum 4,01 untuk mata pelajaran yang diujikan secara nasional, baik untuk nilai ujian teori maupun praktik. Kriteria nilai rerata mata pelajaran lain yang diujikan minimal 6, seperti pada UN 2002/2003 dihapuskan. Tidak seperti UN 2002/2003, UN 2003/2004 memisahkan nilai teori dan nilai praktik dari mata pelajaran yang diujikan secara nasional. Tuntutan semacam tersebut diharapkan mampu mengatrol kualitas penyelenggaraan pendidikan apabila semua yang terlibat dalam penyelenggaraan UN 2003/2004 mempunyai komitmen yang tinggi sesuai ketentuan Standar Prosedur Operasional (SPO) yang telah digariskan pemerintah (Winoto 2004).

\section{UN dalam Perspektif Teori Pengujian}

Secara fisik, UN berupa seperangkat alat pengujian untuk pelajaran Bahasa Inggris, Bahasa Indonesia, dan Matematika. Alat pengujian itu terdiri dari butirbutir tes yang mengukur aspek isi penguasaan siswa dalam pelajaran Bahasa Inggris, Bahasa Indonesia, dan Matematika tersebut, yang masing-masing mengandung dimensi sasaran ukur (Naga 1992:164). Dengan demikian, pada 
UN ada tiga perangkat alat uji yang diujikan secara nasional, beserta sasaran ukur yang telah ditentukan (Lampiran I dan V Surat Keputusan Mendiknas, No. 153/U/2003 Tanggal 14 Oktober 2003).

Mengapa alat uji seperti UN perlu diadakan? Ujian merupakan bagian yang tidak terpisahkan dari kegiatan pemelajaran-pengajaran (misal, Lewy 1977:11; Stiggins 1994:42--57; Nitko 1996:1--20). Setiap kegiatan pemelajaran dan pengajaran diikuti dan atau diiringi dengan suatu kegiatan yang tak terpisahkan lainnya, yaitu ujian. Ujian semacam ini dapat dirancang untuk mengukur setidaknya dua hal (Athanasou, J. dan I. Lamprianou 2002:8), yaitu kemajuan hasil belajar siswa dan keefektifan pengajaran. Tujuan pengukuran hasil belajar sering disebut sebagai achievement orientation; sedangkan tujuan pengukuran keefektivan pengajaran dapat dikategorikan.

Sebagai program evaluation orientation dan kaitannya dengan UN, tersirat adanya dua macam orientasi tersebut, seperti yang tertuang dalam Keputusan Menteri Pendidikan Nasional Republik Indonesia Nomor 114/U/2001 tentang Penilaian Hasil Belajar Secara Nasional, khususnya pasai 3 ayat 1, "mengukur pencapaian hasil belajar peserta didik; dan mengetahui mutu pendidikan ..." dan fungsi memberi "umpan balik perbaikan program pemelajaran". Oleh karena itu, secara teoretis konseptual, nampaknya tujuan dan fungsi yang dijadikan landasan dalam UN memiliki dasar rujukan. Akan tetapi, dalam perspektif ini, yang lebih mendapatkan porsi adalah tujuan "mengukur pencapaian hasil belajar peserta didik"; sedangkan fungsi memberi "umpan balik perbaikan program pemelajaran" dalam sejarah pengujian nasional nampaknya belum pernah dipublikasikan secara luas.

Sebagai alat ukur, tes atau perangkat pengujian harus berkualitas baik (Bachman 1990). Kualitas baik ini perlu karena akurasi dan kualitas informasi yang akan diberikan dari tes (Naga 1992:306) akan bergantung pada kualitas tes atau alat uji yang dikembangkan tersebut. Kualitas informasi ini akan berpengaruh terhadap tindak lanjut yang diambil (Nitko 1996: 9-13). Syarat yang perlu dimiliki sebuah tes atau perangkat uji antara lain reliabilitas, validitas, dan kepraktisannya yang memadai. Secara teoretis, pengujian kualitas tes atau alat uji ini melalui prosedur yang cukup pelik dan memerlukan ketelitian tinggi. UN sebagai alat ukur tentunya perlu melalui prosedur 'standar' pengembangan dan pengujian tes sebelum benar-benar digunakan sebagai alat ukur. Sayangnya, informasi semacam ini tidak mudah untuk diakses secara umum. Akibatnya, yang terkait dengan pengembangan UN adalah asumsi bahwa langkah standar telah dilakukan untuk pengembangannya.

Dalam konsep dikenal adanya istilah tes, pengukuran dan evaluasi (Pedhazur dan Schmelkin, 1991). Ketiga terminologi tersebut mengacu pada konsep yang berbeda. Tes dapat dirujuk sebagai seperangkat prosedur (Bachman 1990) atau butir tes atau seperangkat uji tes (Naga 1992). Bachman (1990) membatasi pengukuran sebagai proses mengkuantifikasikan atribut sasaran ukur dengan menggunakan seperangkat aturan tertentu; sedangkan 
evaluasi dapat dibatasi sebagai proses pengumpulan dan penganalisisan informasi untuk pengambilan keputusan. Dari perspektif konsep dan terminologi tersebut nampaknya ada ketidaktegasan acuan dalam UN. Rancangan istilah UN nampaknya mengacu kepada evaluasi karena di dalamnya ada proses pengambilan keputusan; sedangkan secara bentuk, UN nampaknya menunjuk pada butir-butir tes. Memang dimungkinan bahwa dalam suatu evaluasi melibatkan penggunaan butir tes; namun tidak semua bentuk evaluasi harus menggunakan tes. Istilah assesmen dapat digunakan untuk menggambarkan semangat yang tertuang pada istilah UN. Athanasou, J. dan I. Lamprianou (2002:3) memberi batasan assesmen sebagai "the process or the processes of collecting and combining information from tasks (e.g. tests on performance or learning) with a view to making a judgement about a person or making a comparison against an established criterion".

Istilah ini pun tidak begitu tepat untuk menggambarkan nuansa yang diharapkan pada UN karena ibarat alat potret, UN hanya digunakan untuk 'memotret' kemampuan sesaat siswa saja. Pemotretan keadaan sesaat terhadap seseorang tentu saja tidak dapat digunakan untuk menggambarkan keadaan utuh seseorang. Sementara itu, konsep assesmen yang utuh, seperti batasan di atas, mengisyaratkan adanya "pemotretan" yang dilakukan berkali-kali, dari sudut yang berbeda-beda, dan bahkan dilakukan dengan menggunakan alat yang beragam.

\section{Menganalisis KuriKulum Nasional}

Dalam sistem ketatanegaraan, kurikulum mungkin dapat dipadankan dengan garis besar haluan negara. Dengan garis besar haluan negara, pemerintah memiliki target yang akan dicapai dalam jangka waktu tertentu. Demikian juga, dengan kurikulum, pengelola pendidikan memiliki target yang akan dicapai dengan pemelajaran anak didik.

Satu permasalahan dalam kurikulum nasional adalah bahwa kurikulum yang digunakan terlalu sarat dengan beban dan amat terstruktur. Ini berdampak buruk terhadap kegiatan pemelajaran di kelas. Kurikulum yang sarat dengan beban menjadikan guru berupaya mencapai target beban pencapaian kurikulum dengan berbagai cara. Dampaknya adalah pengajaran menjadi tidak dapat berkembang dengan baik. Pada kondisi seperti ini, guru hanya berupaya mencapai "setoran" sesuai target kurikulum. Guru menjadi tidak kreatif atau inovatif karena saratnya beban yang harus dipikul. Cara yang paling mudah untuk itu adalah metode transfer of knowledge: Guru aktif bicara sementara siswa duduk mendengarkan. Yang terkena imbas adalah siswa. Siswa menjadi terpasung dalam ketidakberdayaan. Kreativitas mereka tidak berkembang, apalagi daya penalaran mereka. Selain itu, kurikulum yang terlalu terstruktur menjadikan pemelajaran tidak luwes dan tidak sesuai dengan perkembangan yang terjadi amat cepat dalam IPTEKS. Pemelajaran menjadi ritual yang tidak memiliki makna karena harus sesuai dengan isi kurikulum. Akibatnya, profesionalisme guru tidak berkembang dengan baik; 
pemelajaran menjadi monoton dan membosankan; proses penilaian hasil belajar menjadi terlalu normatif; dan akhirnya siswa mati kutu.

Berbagai upaya memang telah dilakukan oleh Depdiknas untuk membenahi kurikulum. Upaya-upaya yang dilakukan adalah untuk merampingkan isi, juga untuk membenahi orientasi proses dan hasil belajar siswa (Suyanto 1995b). Namun, dari pengalaman implementasi kurikulum sebelumnya, permasalahan muncul tidak hanya bersumber dari guru, tetapi juga dari kurikulum itu sendiri. Masalah klasik yang muncul adalah seperti yang dipaparkan di atas, yaitu isi kurikulum yang terlalu sarat dan sebagai kurikulum yang tidak terlalu memihak pada guru sebagai orang lapangan. Akibatnya, guru kesulitan menginterpretasikan dan mengimplementasikannya di dalam kegiatan pemelajaran dan pengajaran di kelas. Kendala ini dapat dibaca sebagai langkah awal yang tidak menguntungkan guru untuk menjalankan fungsinya di kelas, termasuk tata cara dan interpretasi pengujian hasil belajar siswa.

\section{Belajar Menerapkan Manajemen Berbasis Sekolah (MBS)}

Kebijakan Departemen Pendidikan Nasional menyatakan bahwa pengguliran manajemen berbasis sekolah merupakan suatu langkah yang seiring dengan kebijakan Pemerintah dalam hal pemberian kewenangan untuk "mengatur" sendiri dalam kerangka konsep otonomi. Untuk jenjang sekolah dasar, kebijakan ini dikenal dengan MBS (Manajemen Berbasis Sekolah), sedangkan untuk jenjang sekolah menengah pertama, kebijakan ini dikenal sebagai MPMBS (Manajemen Peningkatan Mutu Berbasis Sekolah).

Kebijakan Departemen Pendidikan Nasional dalam hal manajemen berbasis sekolah secara teoretis nampaknya dapat ditarik dari perspektif perlunya perubahan-perubahan di sekolah untuk peningkatan mutu pendidikan. Perubahan semacam ini menuntut sinerginya beberapa faktor, seperti berfungsinya kepemimpinan (leadership), pengembangan staf, nilai dan gagasan inovatif, materi dan program yang berkualitas, dan yang paling penting adalah adanya tuntutan bahwa perubahan itu diharapkan dan efektif (Fullan 1982:x). Di antara faktor-faktor tersebut, ada satu faktor yang dominan. Faktor yang dimaksud adalah kepemimpinan (Gunther 2001). Kepala sekolah diharapkan memiliki kualitas kepemimpinan yang dapat diteladani dan menonjol yang akan berperan sebagai lokomotif penggerak rangkaian program dan sumber yang ada di sekolah dan masyarakat sekitar sekolah. Akan tetapi, kepemimpinan dalam konteks ini tidak hanya mengacu kepada kepala sekolah saja. Kepemimpinan bisa juga mengacu pada guru dalam konteks kelasnya. Mereka adalah para pemimpin yang akan mampu mewarnai "budaya kelas dan sekolah" dengan nuansa inovatif untuk kemajuan sekolah. Pemimpin yang berkualitas diharapkan mampu mengelola perencanaan, menggunakan strategi untuk mencapai sasaran, membawa perubahan yang bermakna di sekolah melalui manajemen berbasis sekolah yang dikembangkannya (West-Burnham 1997). 
Bagaimana dengan manajemen berbasis sekolah di dalam konteks pendidikan nasional? Sebagai suatu inovasi dalam pendidikan, manajemen berbasis sekolah dapat ditinjau dari berbagai tataran. Tataran yang paling tinggi adalah tataran konsep. Manajemen berbasis sekolah dalam hal ini berkutat dengan teori tentang pengelolaan sekolah. Tataran di bawahnya adalah tataran kebijakan. Ini adalah tafsiran konsep manajemen berbasis sekolah untuk konteks setempat. Biasanya ini dapat dilihat dari keberadaan dokumen yang dikembangkan oleh pemerintah berkaitan dengan tata cara dan strategi implementasi manajemen berbasis sekolah. Tataran ketiga adalah tataran implementasi. Ini adalah manajemen berbasis sekolah yang benarbenar terjadi di sekolah.

Dalam konteks pendidikan nasional, manajemen berbasis sekolah masih berada dalam tataran dokumen yang terus-menerus diupayakan sosialisasinya melalui berbagai proyek, misalnya melalui Basic Education Project, II, III maupun IV. Di tingkat sekolah dasar, misalnya, dokumen Paket Pelatihan Awal untuk MBS (Direktorat TK dan SD, UNESCO, UNICEF, dan NZAID, 2003) telah diterbitkan dan disosialisasikan di beberapa sekolah dasar pilot project di Jawa Timur, Jawa Tengah, Sulawesi Selatan, dan Nusa Tenggara Timur. Demikian juga untuk tingkat SMP, telah diterbitkan seperangkat dokumen (Buku 1 sd buku 5) tentang manajemen peningkatan mutu berbasis sekolah, dan dokumen lain yang juga mulai disosialisasikan di sekolahsekolah.

Dalam konteks manajemen berbasis sekolah, dalam banyak kasus, pembentukan komite sekolah sebagai mitra kepala sekolah dalam mengelola pendidikan dalam rangka kemajuan sekolah, masih belum dipahami secara proporsional. Akibatnya, masih banyak dijumpai ketimpangan dalam penyelenggaraan manajemen berbasis sekolah. Ada pembentukan komite sekolah yang hanya merupakan syarat karena itu perlu ada di dalam suatu sekolah. Sementara itu, kinerja yang diharapkan belum ada. Ada juga sekolah yang masih menggunakan pola kerja BP3 dalam pemberdayaan komite sekolahnya. Sementara itu, pada sekolah yang telah memiliki komite sekolah yang aktif, malah terjadi tarik-menarik kepentingan, bahkan persaingan antara komite sekolah dan kepala sekolah dalam pengelolaan pendidikan di sekolah. Singkatnya dapat dikatakan bahwa komite sekolah yang diharapkan dapat memberdayakan sekolah melalui partisipasi masyarakat masih belum optimal.

Berdasarkan uraian tersebut, dapat dinyatakan bahwa sekolah sebenarnya sedang dalam tahap mengenali inovasi baru baik dan tingkat pengelolaan pendidikan yang diharapkan akan mampu membawa pada peningkatan mutu pendidikan. Berbagai konsep pengiring manajemen berbasis sekolah juga diperkenalkan, misalnya, pemelajaran kontekstual (Contextual Teaching and Learning) dan pemelajaran aktif kreatif efektif dan menyenangkan (Active Joyful Effective Learning). Ada pula sekolah yang sudah mencoba. Akan tetapi, berdasarkan pengamatan melalui diskusi dalam berbagai kesempatan 
penataran, masih banyak terdapat terminologi yang tidak jelas lapangan seiring dengan implimentasi manajemen berbasis sekolah di antara pengelola pendidikan sendiri, termasuk istilah $\mathrm{KBK}$, portofolio, penilaian otentik, dan masih banyak lagi konsep baru.

\section{VARIABILITAS KarAKTERISTIK GURU}

Pemelajaran di kelas dipandang terlalu berorientasi teoretis. Penguasaan teoretis mendominasi kegiatan pemelajaran siswa. Demikian pula, kegiatan menghafal yang terjadi pada hampir semua mata pelajaran (Khomsan 1995). Kemampuan semacam ini, menurut taksonomi Bloom (Anderson dan Krathwohl 2001) hanya mengajarkan kemampuan dasar kognitif saja, yaitu pengetahuan (knowledge) saja, atau pun kalau ada kemampuan pemahaman (comprehensive). Akibatnya, kemampuan siswa yang lebih tinggi lainnya seperti analisis, aplikasi (application), sintesis (synthesis), dan analisis serta ranah (domain) lainnya, seperti afektif dan psikomotor, tidak berkembang dengan baik. Lebih jauh, Pujihastuti (1995) menengarai terjadinya kemandekan siswa dalam berfikir kreatif. Hal ini hanya akan menghasilkan output pendidikan dengan daya saing siswa yang rendah.

Penyebab keadaan tersebut dapat dilacak dan berbagai sumber, namun salah satu sumber yang berkaitan langsung dengan kegiatan pemelajaran siswa di kelas adalah guru. Ini dapat dimengerti karena guru merupakan unsur penting dalam proses pendidikan. Para gurulah yang berhadapan langsung dengan peserta didik dalam proses pemelajaran mereka. Walaupun ada kualitas unsur lain seperti kurikulum, media pemelajaran, atau sumber belajar lain, pada tataran implementasi, gurulah yang memegang peranan penting dalam mendayagunakan sumber-sumber yang ada dalam kegiatan pemelajaran peserta didik.

Kemampuan guru dapat dipengaruhi oleh banyak faktor. Salah satunya adalah latar belakang pendidikan yang pernah diperolehnya. Hasil survei yang dilakukan oleh Balitbangdiknas (Badan Penelitian dan Pengembangan Pendidikan Nasional) mengungkapkan banyaknya guru SD dan SMP yang memiliki latar belakang pendidikan yang belum memadai. Tabel 2.1 menyajikan ringkasan hasil analisis yang dimaksud.

Tabel 2.1 Persentase Kualifikasi Guru SD dan SMP tiap Provinsi

\begin{tabular}{|l|c|c|c|c|}
\hline \multicolumn{1}{|c|}{ Provinsi } & \multicolumn{2}{c|}{ Guru SD (\%) } & \multicolumn{2}{c|}{ Guru SMP (\%) } \\
\hline & $<\mathrm{D} 2$ & $\geq \mathrm{D} 2$ & $<\mathrm{D} 3$ & $\geq \mathrm{D} 3$ \\
\hline DKI Jakarta & 22.49 & 77.51 & 32.02 & 67.98 \\
\hline Jawa Barat & 29.73 & 70.27 & 26.67 & 73.33 \\
\hline Banten & 32.35 & 67.65 & 26.84 & 73.16 \\
\hline Jawa Tengah & 37.43 & 62.57 & 31.22 & 68.78 \\
\hline DI Yogyakarta & 38.30 & 61.70 & 34.88 & 65.12 \\
\hline
\end{tabular}




\begin{tabular}{|l|c|c|c|c|}
\hline Jawa Timur & 35.88 & 64.12 & 19.65 & 80.35 \\
\hline N. Aceh Darussalam & 69.76 & 30.24 & 44.92 & 55.08 \\
\hline Sumatera Utara & 72.07 & 27.93 & 40.73 & 59.27 \\
\hline Sumatera Barat & 51.31 & 48.69 & 34.28 & 65.72 \\
\hline Riau & 61.66 & 38.34 & 32.95 & 67.05 \\
\hline Jambi & 60.19 & 39.81 & 43.91 & 56.09 \\
\hline Sumatera Selatan & 67.45 & 32.55 & 38.71 & 61.29 \\
\hline Bangka Belitung & 57.75 & 42.25 & 38.65 & 61.35 \\
\hline Bengkulu & 53.69 & 46.31 & 34.77 & 65.23 \\
\hline Lampung & 67.73 & 32.27 & 40.56 & 59.44 \\
\hline Kalimantan Barat & 73.96 & 26.04 & 54.42 & 45.58 \\
\hline Kalimantan Tengah & 68.22 & 31.78 & 34.65 & 65.35 \\
\hline Kalimantan Selatan & 55.86 & 44.14 & 37.49 & 62.51 \\
\hline Kalimantan Timur & 64.79 & 35.21 & 47.83 & 52.17 \\
\hline Sulawesi Utara & 77.94 & 22.06 & 49.92 & 50.08 \\
\hline Gorontalo & 78.50 & 21.50 & 47.78 & 52.22 \\
\hline Sulawesi Tengah & 72.77 & 27.23 & 50.30 & 49.70 \\
\hline Sulawesi Selatan & 64.79 & 35.21 & 45.88 & 54.12 \\
\hline Sulawesi Tenggara & 71.47 & 28.53 & 41.07 & 58.93 \\
\hline Maluku & 65.63 & 34.37 & 37.83 & 62.17 \\
\hline Maluku Utara & 83.50 & 16.50 & 25.20 & 74.80 \\
\hline Bali & 46.53 & 53.47 & 35.76 & 64.24 \\
\hline Nusa Tenggara Barat & 63.56 & 36.44 & 22.49 & 77.51 \\
\hline Nusa Tenggara Timur & 74.39 & 25.61 & 51.67 & 48.33 \\
\hline Papua & 76.26 & 23.74 & 50.88 & 49.12 \\
\hline Rata-rata Nasional & 50,51 & 49,49 & 33,67 & 66,33 \\
\hline
\end{tabular}

Sumber Statistik SD dan SLTP, 2002, Balitbangdiknas

Tabel 2.1 menunjukkan bahwa masih guru SD berlatar belakang pendidikan lebih rendah dari Program Diploma II. Bahkan pada banyak provinsi persentasenya melebihi jumlah rata-rata nasional $(50,51)$. Hal yang mirip juga terjadi di jenjang SMP. Masih ada guru yang mengajar di bawah standar minimum yang ditentukan, yaitu Program Diploma III. Sementara itu, pada beberapa provinsi, persentasenya melebihi rata-rata nasionalnya $(33,67)$. Keadaan yang tidak jauh berbeda dapat diduga juga terjadi pada jenjang SMA.

Apabila latar belakang pendidikan guru dijadikan salah satu faktor yang menentukan kualitas pendidikan, data di atas menunjukkan setidaknya dua hal. Pertama, bervariasinya kualitas latar belakang pendidikan guru di berbagai daerah. Selain itu, juga dapat dikatakan bahwa masih banyak guru yang memiliki syarat kompetensi mengajar di bawah standar yang dipersyaratkan untuk sebuah jenjang pendidikan. Keadaan latar belakang pendidikan guru yang seperti itu tentu saja masih belum memenuhi harapan 
minimal yang ditentukan. Apabila jenjang pendidikan diduga memiliki kontribusi terhadap berbagai aspek karakteristik guru, seperti penguasaan materi pelajaran atau kompetensi mengajar di kelas, dapat diduga kompetensi pada aspek tersebut juga akan berkualitas rendah. Hasil penelitian yang dilakukan oleh Suryadi (1989) mengungkapkan sisi negatif kualitas guru SD di wilayah perkotaan dan daerah dilihat dari penguasaan materi mata pelajaran yang menjadi tanggung jawabnya. Terungkap bahwa penguasaan guru terhadap matematika, bahasa Indonesia, dan sains tergolong rendah. Hal ini dapat dilihat pada Tabel 2.2.

Tabel 2.2 Kualitas Guru SD di Perkotaan dan Daerah terhadap Matematika, B. Indonesia, dan Sains.

\begin{tabular}{|l|l|l|}
\hline Variabel Penguasaan & \multicolumn{2}{|c|}{ Asal } \\
\hline & \multicolumn{1}{|c|}{ Daerah $(\mathrm{n}=1115)$} & Perkotaan $(\mathrm{n}=4533)$ \\
\hline Matematika & $\mathrm{M}=42,3 ; \mathrm{SD}=8,2$ & $\mathrm{M}=44,7 ; \mathrm{SD}=8,4$ \\
\hline B. Indonesia & $\mathrm{M}=34,3 ; \mathrm{SD}=6,2$ & $\mathrm{M}=36,1 ; \mathrm{SD}=5,7$ \\
\hline Sains & $\mathrm{M}=22,4 ; \mathrm{SD}=5,1$ & $\mathrm{M}=22,7 ; \mathrm{SD}=5,4$ \\
\hline
\end{tabular}

Sumber: Adaptasi hasil penelitian Suryadi 1989:36

Permasalahan terkait dengan karakteristik guru tidak berhenti di sini. Guru sebagai unsur penting dalam pendidikan memang dituntut memiliki kualitas yang tinggi karena ada harapan bahwa guru yang berkualitas akan mampu mengelola pendidikan secara memadai di kelas. Pertanyaan lain yang layak dijawab adalah kreativitas dan inovasi guru di kelas. Sutejo (1995) menengarai bahwa dua tuntutan kualitas yang perlu dimiliki guru tersebut, kreativitas dan inovasi guru di kelas, merupakan "barang langka". Artinya, hanya sedikit saja guru yang benar-benar kreatif dan inovatif di kelas. Ada beberapa faktor yang dapat mendorong terjadinya keadaan yang memprihatinkan ini. Salah satu faktor penting adalah kurang profesionalnya guru. Ini terjadi karena guru tidak sempat duduk berpikir untuk meningkatkan kualitas profesinya. Ditengarai bahwa waktu guru banyak terkuras untuk mencari tambahan penghasilan guna memenuhi kebutuhan dasar yang sering tidak mencukupi. Dari iklim seperti ini, dapatkah diharapkan lahimya kreativitas dan inovasi guru di kelas? Ini belum berbicara tentang tuntutan agar guru benar-benar menjadi guru yang reflektif. Guru, menurut Supriyanto (1995) setidaknya mampu melakukan tiga pilar peranannya: (a) menumbuhkan sikap ilmiah, (b) membiasakan siswa dalam menggunakan metode ilmiah, dan (c) peka terhadap perkembangan IPTEKS. Menurut Suyanto (1995), guru harus memahami penelitian dalam konteks profesinya, setidaknya melalui penelitian tindakan kelas.

Berdasarkan data di atas, dapat dinyatakan bahwa kondisi kualitas guru dapat dikategorikan rendah dan bervariasi. Apabila hal yang utama dari 
seorang guru, yaitu penguasaan materi pelajaran atau kompetensi mengajar di kelas rendah, dapatkah diharapkan terjadinya pemelajaran yang bermutu di kelas yang menuju terbentuknya penguasaan siswa yang juga bermutu?

\section{DisParitas Kondisi FASILITAS PENDIDIKAN}

Fasilitas pendidikan juga dipandang merupakan unsur penunjang proses pendidikan. Artinya, kualitas proses pendidikan di kelas sedikit banyak akan terpengaruhi oleh fungsionalitas fasilitas pendidikan yang ada. Bagaimanakah kondisi fasilitas pendidikan yang ada di lapangan?

Fasilitas pendidikan dapat diartikan sebagai sarana dan prasarana pendidikan. Hal ini dapat ditinjau dari berbagai segi. Suryadi (tanpa tahun) mengkaji aspek ini dari segi fasilitas sekolah, peralatan kelas, dan buku yang ada di sekolah-sekolah dasar di daerah dan perkotaan di provinsi Jawa Barat, Sulawesi Selatan dan NTB. Hasil kajian yang dilakukannya dipaparkan pada Tabel 2.3.

Tabel 2.3 Persentase Keadaan Fasilitas Sekolah

\begin{tabular}{|l|c|c|}
\hline \multicolumn{1}{|c|}{ Sarana dan Prasarana } & \multicolumn{2}{|c|}{ Persentase } \\
\hline & $\begin{array}{c}\text { Wilayah Daerah } \\
(\mathrm{n}=1115)\end{array}$ & $\begin{array}{c}\text { Wilayah Perkota- } \\
\text { an (n=4537) }\end{array}$ \\
\hline 1. Fasilitas Sekolah: & & 43 \\
\hline 1.1. Ruang guru & 37 & 36,6 \\
\hline 1.2. Perpustakaan & 26 & 6,1 \\
\hline 1.3. Laboratorium & 5,1 & 14 \\
\hline 1.4. Kafetaria & 59 & 73,5 \\
\hline 1.5. Kamar Kecil & & 43,6 \\
\hline 2. Peralatan Kelas & 35,1 & 55,2 \\
\hline 2.1. Meja Siswa & 36,1 & 78,2 \\
\hline 2.2. Meja Guru & 67,6 & 53 \\
\hline 2.3. Papan Tulis & & 54 \\
\hline Buku & 46,52 & \\
\hline 3.1. Buku Kelas 1--VI (rerata) & 47,20 & \\
\hline 3.2. Buku Pegangan Guru & & \\
\hline
\end{tabular}

Data pada tabel 2.3 menunjukkan bahwa fasilitas sekolah, peralatan kelas, dan buku baik di sekolah dasar di daerah perkotaan maupun di daerah belum mencukupi. Artinya, sekolah dasar di provinsi Jawa Barat, Sulawesi Selatan, dan Jawa Barat, belum semua memiliki fasilitas sekolah, peralatan kelas, dan buku. Keadaan serupa diduga juga terjadi di provinsi-provinsi lainnya.

Bagaimana dengan kondisi sarana dan prasarana yang lebih besar lagi, yaitu ruang kelas? Ruang kelas yang baik merupakan sarana yang menunjang terjadinya pemelajaran yang bermutu di kelas. Apakah ruang kelas yang baik 
kondisinya telah dapat dipenuhi oleh semua sekolah? Berikut adalah data yang dikumpulkan oleh Balitbang Diknas.

Tabel 2.4 Kondisi Ruang Kelas tiap Provinsi

\begin{tabular}{|l|r|c|r|r|r|r|}
\hline Provinsi & \multicolumn{3}{|c|}{ SD/MI } & \multicolumn{3}{|c|}{ SMP/MTs } \\
\hline & $\begin{array}{c}\text { Rusak } \\
\text { Berat } \\
(\%)\end{array}$ & $\begin{array}{c}\text { Rusak } \\
\text { Ringan } \\
(\%)\end{array}$ & $\begin{array}{c}\text { Baik } \\
(\%)\end{array}$ & $\begin{array}{c}\text { Rusak } \\
\text { Berat } \\
(\%)\end{array}$ & $\begin{array}{c}\text { Rusak } \\
\text { Ringan } \\
(\%)\end{array}$ & $\begin{array}{c}\text { Baik } \\
(\%)\end{array}$ \\
\hline DKI Jakarta & 4.48 & 14.64 & 80.88 & 2.26 & 9.76 & 87.98 \\
\hline Jawa Barat & 32.40 & 36.45 & 31.15 & 5.20 & 10.92 & 83.88 \\
\hline Banten & 25.74 & 28.25 & 46.00 & 4.93 & 10.59 & 84.48 \\
\hline Jawa Tengah & 18.94 & 38.37 & 42.69 & 1.49 & 7.76 & 90.74 \\
\hline DI Yogyakarta & 14.13 & 40.70 & 45.17 & 2.38 & 8.40 & 89.21 \\
\hline Jawa Timur & 17.55 & 36.87 & 45.58 & 1.96 & 6.37 & 91.67 \\
\hline N. Aceh Darussalam & 23.25 & 34.91 & 41.84 & 4.21 & 10.93 & 84.86 \\
\hline Sumatra Utara & 20.22 & 38.64 & 41.14 & 3.74 & 9.65 & 86.61 \\
\hline Sumatra Barat & 18.24 & 38.88 & 42.89 & 4.47 & 10.99 & 84.54 \\
\hline Riau & 30.54 & 28.62 & 40.84 & 0.92 & 4.20 & 94.88 \\
\hline Jambi & 22.26 & 25.61 & 52.12 & 3.48 & 9.14 & 87.38 \\
\hline Sumatra Selatan & 21.74 & 33.17 & 45.09 & 1.90 & 6.50 & 91.60 \\
\hline Bangka Belitung & 13.26 & 29.93 & 56.81 & 1.95 & 6.56 & 91.50 \\
\hline Bengkulu & 31.56 & 35.66 & 32.78 & 6.61 & 14.08 & 79.32 \\
\hline Lampung & 28.70 & 45.60 & 25.70 & 2.86 & 8.83 & 88.31 \\
\hline Kalimantan Barat & 28.39 & 33.32 & 38.29 & 2.87 & 9.67 & 87.46 \\
\hline Kalimantan Tengah & 30.92 & 31.47 & 37.61 & 1.83 & 3.48 & 94.69 \\
\hline Kalimantan Selatan & 27.52 & 33.18 & 39.30 & 3.40 & 11.01 & 85.58 \\
\hline Kalimantan Timur & 22.31 & 36.00 & 41.70 & 3.42 & 9.29 & 87.29 \\
\hline Sulawesi Utara & 17.16 & 33.04 & 49.79 & 7.23 & 17.40 & 75.37 \\
\hline Gorontalo & 21.86 & 32.95 & 45.19 & 7.54 & 12.87 & 79.59 \\
\hline Sulawesi Tengah & 34.03 & 33.00 & 32.97 & 3.53 & 6.85 & 89.62 \\
\hline Sulawesi Selatan & 19.69 & 31.52 & 48.78 & 4.08 & 11.08 & 84.83 \\
\hline Sulawesi Tenggara & 31.99 & 33.12 & 34.89 & 3.74 & 9.01 & 87.25 \\
\hline Maluku & 36.24 & 30.98 & 32.78 & 9.57 & 13.74 & 76.69 \\
\hline Maluku Utara & 38.07 & 29.50 & 32.43 & 9.46 & 18.72 & 71.82 \\
\hline Bali & 20.08 & 35.33 & 44.59 & 4.79 & 10.33 & 84.88 \\
\hline NTB & 16.64 & 32.97 & 50.39 & 1.68 & 9.63 & 88.69 \\
\hline NTT & 36.68 & 29.37 & 33.96 & 7.40 & 11.94 & 80.66 \\
\hline Papua & 23.42 & 25.49 & 51.09 & 9.47 & 8.38 & 82.15 \\
\hline Rata-rata Nasional & 24.27 & 32.92 & 42.82 & 4.28 & 9.94 & 85.78 \\
\hline
\end{tabular}

Sumber: Statistik SD dan SLTP, 2002, PDIP Balitbangdiknas

Data pada Tabel 2.4 menunjukkan bahwa jenjang SD maupun SMP memiliki kondisi ruang kelas sekolah yang bervariasi mulai dan rusak, rusak 
ringan, dan baik. Kondisi kerusakan nampaknya lebih banyak terjadi di SD dibandingkan di SMP. Selain itu, terlihat bahwa masih ada sekolah, baik SD maupun SMP, yang kondisi ruang kelasnya belum memadai untuk kegiatan pemelajaran siswa.

\section{FAKTA EMPIRIS TENTANG Hasil Belajar Siswa}

Yang dimaksud dengan fakta empiris pada bagian ini adalah skor hasil tes dan Nilai Ebtanas Murni dan Ujian Akhir Nasional. Skor hasil tes bersumber dari penelitian Suryadi; sedangkan nilai Ebtanas Murni bersumber dari Pusat Sistem Pengujian, Depdiknas dari data hasil ujian yang dikumpulkan pada tahun 2003.

Penelitian Suryadi pada tahun 1989 mengungkapkan temuan yang memprihatinkan tentang hasil belajar siswa SD pada tiga mata pelajaran, yaitu Matematika, Bahasa Indonesia, dan Sains. Penelitian yang dilakukan di tiga provinsi, yaitu Jawa Barat, Sulawesi Selatan, dan NTB, mengungkapkan rendahnya rerata hasil belajar siswa pada tiga mata pelajaran tersebut $($ matematika $=27,7$; Bahasa Indonesia $=21,6$; dan sains $=24,2)$. Hasil belajar ini tidak jauh berbeda dengan hasil belajar siswa SD yang ditemukan oleh peneliti lain pada lebih sepuluh tahun sebelumnya. Hal ini dapat dilihat pada Tabel 2.5.

Tabel 2.5. Hasil Belajar Siswa SD dalam B.Indonesia, Matematika, dan Sains

\begin{tabular}{|l|l|l|l|}
\hline Penelitian Th. 1989 & \multicolumn{3}{|c|}{ Mata Pelajaran } \\
\hline & \multicolumn{1}{|c|}{ B. Indonesia } & \multicolumn{1}{c|}{ Matematika } & \multicolumn{1}{c|}{ Sains } \\
\hline Rerata & 27,7 & 21,6 & 24,2 \\
\hline SD & 7,9 & 8,7 & 6,8 \\
\hline Total Butir & 47 & 49 & 47,0 \\
\hline \% Jawaban Benar & 58,9 & 44,1 & 52,5 \\
\hline
\end{tabular}

\begin{tabular}{|l|l|l|l|}
\hline Penelitian Th. 1976 & \multicolumn{3}{|l|}{} \\
\hline Rerata & 35,0 & 33,0 & 27,0 \\
\hline SD & 12,0 & 9,0 & 8,0 \\
\hline Total Butir & 60 & 60 & 60 \\
\hline \% Jawaban Benar & 49,0 & 55,0 & 45,0 \\
\hline
\end{tabular}

Sumber: Adaptasi Laporan Penelitian Suryadi tahun 1989

Data nilai EBTANAS tahun 2000/2001 untuk jenjang SMP/MTs. (Kebijakan Direktorat PLP, 2004:17-18) dapat disarikan sebagai berikut:

1. SMP yang memiliki kategori EBTANAS baik sekali ada 0,03\% (EBTANAS> 7,5);

2. SMP yang memiliki kategori EBTANAS baik (EBTANAS 6,5 $-<7,5$ ) ada $2,14 \%$; 
3. SMP yang memiliki EBTANAS sedang ada 21,95\%(EBTANAS 5,5 - < 6,5);

4. SMP yang memiliki EBTANAS kurang (EBTANAS 4,5 - <5,5) ada 68,37\%, dan

5. SMP yang memiliki EBTANAS sangat kurang ada 7,46\% (EBTANAS < $4,5)$.

Data tersebut menunjukkan bahwa hasil beiajar siswa apabila diukur dengan menggunakan EBTANAS, secara umum masih tergolong memprihatinkan. Sementara itu, terlepas dari berbagai kontroversi yang berkembang di masyarakat, nilai ujian akhir nasional memang dapat digunakan sebagai cerminan masalah yang terjadi dalam pendidikan. Tabel 2.6 menunjukkan ringkasan rata-rata hasil UN SMP antarprovinsi.

Tabel 2.6 Rata-rata Nilai UN SMP antar Provinsi Tahun 2002/ 2003

\begin{tabular}{|c|c|c|}
\hline \multirow[t]{2}{*}{ Provinsi } & \multicolumn{2}{|c|}{ Nilai } \\
\hline & $\geq 5,93$ & $<5,93$ \\
\hline DKI & 6,22 & \\
\hline Jabar & & 5,96 \\
\hline Banten & & 5,93 \\
\hline Jateng & & 5,93 \\
\hline DIY & 6,41 & \\
\hline Jatim & 6,41 & \\
\hline NAD & & 5,41 \\
\hline Sumut & & 5,76 \\
\hline Sumbar & 6,24 & \\
\hline Riau & & 5,11 \\
\hline Jambi & & 5,78 \\
\hline Sumsel & & 5,73 \\
\hline Bangka Belitung & & 5,93 \\
\hline Bengkulu & & 4,86 \\
\hline Lampung & & 5,74 \\
\hline Kalbar & & 5,56 \\
\hline Kalteng & & 5,51 \\
\hline Kalsel & & 5,56 \\
\hline Kaltim & & 5,76 \\
\hline Sulut & & 5,53 \\
\hline Gorontalo & & 5,53 \\
\hline Sulteng & & 5,74 \\
\hline Sulsel & 6,30 & \\
\hline Sultra & & 5,80 \\
\hline Maluku & & 4,23 \\
\hline Maluku Utara & 6,00 & \\
\hline
\end{tabular}




\begin{tabular}{|c|c|c|}
\hline \multirow[t]{2}{*}{ Provinsi } & \multicolumn{2}{|c|}{ Nilai } \\
\hline & $\geq 5,93$ & $<5,93$ \\
\hline Bali & 6,18 & \\
\hline NTB & & 4,03 \\
\hline NTT & & 5,46 \\
\hline Papua & & 4,72 \\
\hline
\end{tabular}

Sumber: Balibang Pusisjian, Depdiknas, September 2003

Data pada Tabel 2.6 memperlihat bahwa hanya 7 (tujuh) provinsi $(25,93 \%)$ yang memiliki nilai UN yang sama atau lebih tinggi dibandingkan dengan nilai tingkat nasional (> 5,93 poin). Ketujuh provinsi tersebut adalah DKI Jakarta, DI Yogyakarta, Jawa Timur, Sumatera Barat, Sulawesi Selatan, Maluku Utara, dan Bali. Sementara itu, sebagian besar provinsi lainnya $(74,07 \%)$ memiliki nilai UN yang berada di bawah standar nilai nasional ( $<5,93$ poin). Informasi ini mengisyaratkan bahwa hasil belajar akhir siswa masih rendah.

Berdasarkan pembahasan tersebut, terlihat bahwa aspek pengelolaan kurikulum, pengelolaan sekolah melalui manajemen berbasis sekolah, karakteristik guru, fasilitas pendidikan yang ada, dan siswa sebagai cerminan hasil pendidikan masih memiliki tantangan yang perlu mendapatkan perhatian. Intensitas perhatian dan tindak lanjut ini nampaknya lebih mengarah pada terpenuhinya syarat kebutuhan pengajaran dan pemelajaran minimal yang baik. Ini bukan berarti bahwa evaluasi tidak penting. Dalam konteks ini diperlukan prioritas penanganan untuk peningkatan mutu pendidikan. Evaluasi secara nasional tentu saja memerlukan biaya yang tidak sedikit, baik secara uang, tenaga maupun pikiran. Biaya tersebut kemungkinan akan lebih efektif dan efisien apabila dialokasikan terlebih dahulu untuk pemenuhan kebutuhan "fisik minimal" pengajaran dan pemelajaran di kelas atau sekolah dalam skala lokal.

\section{Beber apa Agenda ke Depan: Kerangka Dasar Pemikiran}

Terkait dengan UN yang menimbulkan kontroversi seperti yang dipaparkan di atas, nampaknya diperlukan suatu kerangka pemikiran yang dapat digunakan sebagai landasan untuk pembangunan pendidikan nasional, khususnya melalui UN. Oleh karena itu, diperlukan strategi penataan pola pikir. Penataan pola pikir ini merupakan sarana untuk merumuskan dan mendudukkan masalah pada tempatnya. Selanjutnya, berdasarkan permasalahan yang teridentifikasi, kemudian diidentifikasi pendekatan pemecahan masalah yang dapat dilakukan beserta caranya jika pendekatan yang dilakukan selama ini tidak memberikan hasil yang memuaskan.

Pembangunan sumber daya manusia (SDM) memberikan output yang tidak instan atau langsung dan dapat dilihat hasilnya secara konkret, seperti dampak pembangunan fisik lainnya. Diperlukan jangka panjang untuk melihat dampak output pendidikan manusia sehingga menjadi outcome fungsional yang sebenarnya seperti yang diharapkan. Selain itu, pembangunan SDM 
memerlukan sumber dana dan sumber daya yang besar. Oleh karena itu, untuk menghindari kekeliruan yang akan berakibat pada penghamburan dana dan kesia-siaan program pembangunan pendidikan, terutama yang berkait dengan UN, perlu dilakukan pentahapan penataan sistem pengujian. Ada tiga tahap yang dapat dilakukan, yaitu tahap konsolidasi (consolidation stage), tahap pemantapan (establishment stage), dan tahap pengembangan (development stage). Ketiga tahap tersebut masing-masing perlu diproyeksikan secara akurat dalam kerangka acuan waktu sebagai jangka pendek, menengah, dan panjang.

Tahap konsolidasi adalah tahap pertama yang perlu dilakukan. Sesuai dengan namanya, tahap ini ditujukan untuk mengkaji ulang permasalahanpermasalahan yang ada terkait dengan otonomi pendidikan. Terutama masalah yang berhubungan dengan pemenuhan kebutuhan pelayanan pendidikan minimal, baik ditinjau dari segi sarana, prasarana, maupun proses pendidikan. Pada tahap ini akan perlu diidentifikasi sekolah-sekolah yang telah maupun yang belum mendapatkan pelayanan pendidikan secara memadai. Output tahap ini adalah daftar sekolah sesuai dengan klasifikasinya. Acuan formal dasar untuk mengklasifikasikan sekolah-sekolah adalah Bab IX Pasal 35 UU R1 No. 20. Th. 2003 tentang Sistem Pendidikan Nasional.

Juga perlu diidentifikasi kelemahan dan kelebihan masing-masing daerah terkait dengan penyelenggaraan sistem pengujian hasil belajar siswa. Pada tahap ini akan teridentifikasi sekolah-sekolah yang belum atau yang sudah mampu secara akademis dengan prosedur yang benar untuk menyelenggarakan sistem ujian hasil belajar siswa, termasuk jangkauan kelemahan atau kelebihan tiap-tiap sekolah. Dengan demikian, akan teridentifikasi kelompok-kelompok sekolah dengan karakteristiknya pada suatu wiiayah atau daerah tertentu untuk penyelenggaraan pengujian hasil belajar siswa. Karakteristik ini akan mencerminkan jenjang kemampuan masing-masing, mulai dari jenjang yang paling bawah hingga jenjang yang paling atas, yaitu sekolah yang memenuhi standar nasional dalam kerangka Manajemen Berbasis Sekolah (MBS).

Selain itu, perlu dikaji sistem pengujian yang pemah dilakukan di daerah dan diidentifikasi tingkat keberhasilan dan kegagalannya. Ini penting karena sistem tersebut mungkin akan berguna sebagai dasar untuk pembenahan pada tahap selanjutnya. Kegiatan-kegiatan pada tahap konsolidasi ini dilakukan untuk program jangka pendek, mungkin satu atau dua tahun.

Tahap selanjutnya adalah pemantapan sistem pengujian hasil belajar siswa. Setelah sekolah-sekolah dengan berbagai karakteristiknya teridentifikasi, langkah selanjutnya adalah perlunya pemantapan sistem pengujian. Yang dimaksud dengan pemantapan sistem pengujian adalah penerapan sistem pengujian sesuai dengan karakteristik sekolah. Ini berarti bahwa sesuai dengan prinsip otonomi sekolah dalam wadah manajemen berbasis sekolah (MBS), penyelenggaraan pengukuran hasil belajar siswa untuk sekolah yang berbeda akan menerapkan sistem yang berbeda pula, tetapi masih dalam 
koridor ketentuan nasional yang berlaku. Dalam konteks seperti ini, sekolah yang memiliki "kelebihan" akan menyelenggarakan pengujian hasil belajar siswanya berbeda dengan sekolah yang masih "lemah".

Tahap pemantapan ini perlu dilakukan dengan asas provisional, dinamis, dan progresif. Oleh karena itu, perlu dilakukan penilaian secara berkala pada sekolah-sekolah sebagai sistem penyelenggara pendidikan secara berkala untuk menentukan status kemampuan tiap-tiap sekolah. Ini dapat dilakukan melalui evaluasi diri yang diikuti dengan kunjungan lapangan. Sekolah yang berstatus lemah, tetapi memiliki penyelenggaraan manajemen berbasis sekolah yang baik, akan mengalami peningkatan status. Sebaliknya, sebuah sekolah yang pada awalnya dikategorikan baik sangat mungkin akan turun kedudukannya karena penyelenggaraan manajemen berbasis sekolah yang kurang memadai. Sistem pengujian hasil belajar siswa pada masing-masing sekolah, itu akan bersifat sementara (provisional) bergantung pada status predikat setelah, dan ini akan terus berkembang (dinamis) dari waktu ke waktu, untuk mencapai tingkat kemajuan (progresif) sesuai yang diisyaratkan pada Bab IX Pasal 35 UU Rl No. 20. Th. 2003 tentang Sistem Pendidikan Nasional dan tentang Standar Pendidikan Nasional. Tahap ini dapat diselenggarakan setelah tahap konsolidasi dalam kurun waktu lima tahunan.

Tahap ketiga yang perlu dilakukan adalah tahap pengembangan. Tahap ini difokuskan pada kualitas penyelenggaraan dan pemberdayaan hasil pengujian. Asas yang digunakan untuk melaksanakan tahap pengembangan ini adalah selektif, komprehensif, dan fungsional. Pada tahap ini, tidak semua sekolah akan diukur hasil belajar siswanya. Sekolah-sekolah yang benar-benar memenuhi standar sesuai dengan yang diisyaratkan pada Bab IX Pasal 35 UU Rl No. 20. Th. 2003 tentang Sistem Pendidikan Nasional, tentang Standar Pendidikan Nasional itulah yang akan diuji. Sekolah-sekolah yang belum memenuhi ketentuan akan diberikan peluang untuk mengembangkan diri sehingga mencapai standar nasional. Aspek yang dinilai hendaknya komprehensif, mencakup semua pelajaran yang benar-benar menjadi fokus garapan pada suatu Garis-garis Besar Haluan Negara, sesuai perkembangan IPTEKS. Penilaiannya pun bukan untuk mengevaluasi siswa, tetapi lebih diarahkan pada penilaian sekolah sebagai suatu sistem penyelenggara pendidikan. Hasil pengujian akan dimanfaatkan sebagai balikan bagi sekolah untuk secara sistematis dan fungsional memperbaiki kelemahan dan meningkatkan kualitas kinerjanya. Tahap ini sebaiknya sudah ditangani oleh Lembaga Penjamin Mutu Pendidikan (LPMP) atau lembaga independen lain yang bergerak dalam bidang evaluasi untuk menilai penyelenggaraan pendidikan. 


\section{REDEFINISI DAN REPOSISI TUJUAN DAN FUNGSI UN SERTA TRANSPARANSI DARI IMPLEMENTASINYA}

Seperti yang dipaparkan pada bagian terdahulu, tidak semua tujuan maupun fungsi UN, baik yang tertuang dalam Keputusan Menteri Pendidikan Nasional Republik Indonesia Nomor 114/U / 2001 tentang Penilaian Hasil Belajar Secara Nasional, maupun dalam Keputusan Menteri Pendidikan Nasional Republik Indonesia Nomor 153/U / 2003 Tanggal 14 Oktober 2003 tentang Ujian Akhir Nasional Tahun Pelajaran 2003/2004, dapat diketahui secara luas oleh publik. Tujuan yang diketahui secara luas karena menyentuh kepentingan masyarakat adalah tujuan untuk

(a) mengukur pencapaian hasil belajar peserta didik. Tujuan-tujuan lain seperti (b) mengukur mutu pendidikan di tingkat nasional, provinsi, kabupaten/kota, dan sekolah/ madrasah; (c) mempertanggungjawabkan penyelenggaraan pendidikan secara nasional, provinsi, kabupaten/kota, dan sekolah/madrasah kepada masyarakat tidak bergaung dalam masyarakat.

Sementara itu, fungsi (C) tampaknya di luar perhatian masyarakat luas. ‘Bahan dalam menentukan kelulusan peserta didik' juga lebih diketahui masyarakat karena ini menyentuh kehidupan mereka. Fungsi lainnya, seperti UN sebagai

(a) alat pengendali mutu pendidikan secara nasional; (b) pendorong peningkatan mutu pendidikan; dan (c) bahan pertimbangan dalam seleksi penerimaan peserta didik baru pada jenjang pendidikan yang lebih tinggi.

Ini diduga karena fungsi UN tersebut tidak tersosialisasikan dengan baik dan secara konsep kemungkinan tidak mudah untuk diketahui realisasinya.

Terkait dengan masalah ini nampaknya perlu dilakukan redefinisi, reposisi dan transparansi dari implementasi tujuan dan fungsi UN. Pertama, salah satu hal yang penting yang terungkap dalam pembahasan di atas adalah kekurang tepatan penggunaan istiiah. Istilah yang mungkin mendekati nuansa UN adalah assesmen. Dengan demikian, UN dapat diberi batasan ulang sebagai assesmen akhir nasional, yaitu proses menyeluruh yang bertujuan mengumpulkan dan menganalisis data yang dikumpulkan melalui berbagai cara dengan tujuan untuk membuat keputusan mengenai sekolah sebagai penyelenggara pendidikan berdasarkan ketentuan-ketentuan yang ditentukan secara nasional dalam kerangka manajemen berbasis sekolah.

Apabila definisi ini telah ditetapkan, langkah selanjutnya adalah menempatkan kembali tujuan dan fungsi assesmen nasional. Dalam assesmen nasional semacam ini, tujuan utama bukan (a) mengukur pencapaian hasil belajar peserta didik tetapi lebih pada 'mengukur mutu pendidikan di tingkat nasional, provinsi, kabupaten/kota, dan mempertanggungjawabkan penyelenggaraan pendidikan secara nasional, provinsi, kabupaten/kota, 
dan sekolah/madrasah kepada masyarakat, yaitu berturut-turut tujuan (b) dan (c) dari UN. Sementara itu, tujuan mengukur pencapaian hasil belajar peserta didik diserahkan kepada sekolah masing-masing. Tentu saja dalam skema peringkat manajemen berbasis sekolah dari masing-masing sekolah seperti yang telah dipaparkan di bagian kerangka dasar pemikiran di atas. Sementara itu, fungsi assesmen nasional juga seiring dengan tujuannya. Dengan demikian, fungsi-fungsi (c) bahan dalam menentukan kelulusan peserta didik dan (d) bahan pertimbangan dalam seleksi penerimaan peserta didik baru pada jenjang pendidikan yang lebih tinggi dapat dikesampingkan. Jadi, fungsi assesmen nasional adalah (a) alat pengendali mutu pendidikan secara nasional; dan (b) pendorong peningkatan mutu pendidikan.

Langkah konkret yang perlu dilakukan selanjutnya, apabila redefinisi dan reposisi tujuan dan fungsi telah dilakukan, adalah aktualisasi tujuan dan fungsi assesmen nasional tersebut secara konkret dan konsisten. Dengan kata lain, perlu ada transparansi dalam implementasi tujuan dan fungsi assesmen nasional tersebut kepada publik. Ini tentu saja perlu dilakukan pertama-tama dengan sosialisasi program secara intensif dan ekstensif kepada seluruh masyarakat. Tujuannya adalah memahami konsep assesmen nasional secara benar sehingga program ini akan memperoleh dukungan masyarakat secara luas. Hal lain yang penting dilakukan dalam skema assesmen nasional adalah transparansi dalam implementasi program dan hasil assesmennya.

\section{Pemberdayaan Assesmen Hasil Belajar Berbasis Kelas}

Ada pelajaran yang amat berharga dari penyelenggaraan SPMB atau UMPTN yang kiranya dapat digunakan sebagai cerminan apabila UN masih diselenggarakan dalam format seperti yang dilakukan seperti sekarang ini. Pengalaman pertama adalah apa yang disebut negative backwash effect. Backwash effect dalam konteks tes merupakan suatu hal yang perlu diperhatikan (Bachman 1990). Efek cucibalik ini maksudnya adalah dampak balik tes terhadap setidaknya dua hal, yaitu pemelajaran siswa dan aktivitas pengajaran siswa.

Seperti yang telah diketahui secara umum, SPMB atau UMPTN telah melahirkan berbagai lembaga pendidikan di luar sekolah yang menjanjikan bantuan belajar kepada calon peserta SPMB atau UMPTN agar mereka berhasil lolos dalam ujian. Praktik yang dilakukan dalam pemberian bantuan adalah pemecahan soal-soal yang mirip dengan soal SPMB atau UMPTN. Pemelajaran semacam ini yang berorientasi pada pemenuhan kebutuhan sesaat akan cenderung menggiring peserta untuk tidak mempelajari esensi materi, tetapi lebih pada strategi agar lolos ujian. Akibatnya, semua kegiatan pemelajaran diarahkan pada strategi lolos ujian, yaitu dengan menggunakan berbagai cara belajar yang mengarah pada bentuk soal yang akan diujikan. Ini, kalau tidak dipahami dengan benar, akan berpotensi menjerumuskan siswa karena kemampuan berfikir lain tidak berkembang. Hal yang sama juga akan dilakukan oleh guru. Guru akan mengajarkan materi-materi yang 
sekiranya hanya akan diujikan saja dengan bentuk pemecahan masalah, seperti format yang digunakan dalam ujian. Apabila situasi ini terjadi, maka akan terjadi proses sinkretisasi dalam pendidikan nasional. Hal ini berbahaya bagi perkembangan kualitas sumber daya manusia, yang gejala-gejalanya nampaknya mulai dapat dilihat sekarang: menggunakan berbagai cara yang tidak benar untuk mencapai tujuan.

Lalu, apa yang dapat dilakukan untuk mengevaluasi hasil belajar siswa? Sesuai dengan jiwa otonomi, satu langkah strategis adalah pemberdayaan evaluasi hasil belajar berbasis kelas. Dalam kerangka evaluasi hasil belajar berbasis kelas, guru memiliki kewenangan yang lebih untuk menilai hasil belajar siswanya. Ini relevan karena dalam kesehariannya gurulah yang bergaul dalam proses pemelajaran dengan siswa. Dengan demikian, guru benar-benar memahami kelemahan dan kelebihan siswa. Semua ini tentu saja dilakukan dalam kerangka manajemen berbasis sekolah. Guru memang berwenang penuh, namun ia tidak dapat semata-mata berbuat sesuka hatinya. Ada mekanisme pengawasan yang melibatkan masyarakat. Jadi, guru akan bertanggung jawab kepada masyarakat atas penilaian yang dilakukannya kepada siswa. la harus mampu menjelaskan makna kemajuan belajar siswa kepada orang tua siswa.

Penilaian berbasis kelas kelihatannya merupakan jawaban yang hampir adil. Akan tetapi, secara konsep, penilaian berbasis kelas ini memerlukan komitmen dan profesionalisme yang baik. Penilaian bukan dalam kerangka penentuan naik tidak, tetapi pada bantuan belajar apa yang dapat dilakukan pada siswa. Seorag guru benar-benar dituntut untuk bersungguh-sungguh mengenali kelebihan dan kekurangan masing-masing individu siswanya. Tanpa ini, nampaknya akan sulit mengimplementasikan penilaian berbasis kelas. Selain itu, guru juga dituntut profesional. la harus benar-benar menguasai materi, kurikulum, prinsip pemelajaran, dan assesmen secara mantap (Stiggins, 1994).

Hal lain yang penting yang dapat mendukung kinerja profesionalisme guru dalam konteks penilaian berbasis kelas adalah perlu adanya perampingan muatan kurikulum nasional. Pemerintah pusat hendaknya mampu mengembangkan semacam national outcomes of education sebagai penjabaran yang lebih operasional dari Garis Garis Besar Haluan Negara (GBHN). National outcomes ini akan berfungsi semacam petujuk arah (signpost) yang akan mengarahkan daerah-daerah dalam pencapaian kompetensikompetensi yang ditetapkan secara nasional. Dengan tetap mengacu pada national outcomes of education, daerah diberi kebebasan untuk menerjemahkan sendiri-sendiri kebutuhan setempat sesuai dengan kondisi, kelemahan, dan kelebihan daerah masing-masing. Seperti penilaian berbasis kelas, pencapaian tujuan lokal ini juga berlandaskan acuan manajemen berbasis sekolah. 


\section{PENUTUP}

Berdasarkan pembahasan di atas, dapat dikatakan bahwa untuk meningkatkan mutu pendidikan nasional melalui assesmen nasional perlu dilakukan pembenahan di semua ini. Selain itu, perlu upaya yang dilakukan secara berjenjang dalam konsep manajemen berbasis sekolah. Satu program pendidikan nasional yang berpotensi sebagai andalan adalah program Wajib Belajar (WAJAR) 9 Tahun (Forum Koordinasi Nasional Pendidikan untuk Semua, 2004) yang perlu diperkuat dan dikoordinasikan dalam kerangka UN.

Yang jadi pertanyaan. Siapa yang membenahi? Pemerintah pusat atau pemerintah daerah? Sebenarnya, pemerintah pusat dan pemerintah daerah dapat saling membentuk jaringan sinergis. Pemerintah pusat-sesuai peran, kedudukan, dan tanggung jawabnya- perlu membuat national guidelines yang ramping dan visioner. Itu adalah kewajiban yang tidak dapat ditawar. National guidelines akan menjadi semacam acuan nasional bagi semua penyelenggara pendidikan di daerah. Satu hal yang perlu disadari ialah national guidelines berperan sebagai guidepost, yakni semacam garis besar haluan negara atau rambu-rambu yang memberi visi arahan yang tidak bersifat preskriptif atau memaksa.

Peran dan tanggung jawab pemerintah daerah hendaknya dilihat dalam perspektif otonomi daerah. Mereka bukanlah sekadar pelaksana kebijakan pusat (to implement) yang hidup matinya bergantung pada kebijakan pusat. Namun, mereka adalah pembuat sekaligus pelaksana kebijakan yang diimplementasikan dalam koridor rambu-rambu nasional. Dalam kerangka otonomi daerah, jika benar bahwa sumber daya keuangan ada di daerah dan daerah memiliki aspirasi yang jelas tentang apa yang dapat mereka kembangkan sesuai dengan kondisi setempat masing-masing, termasuk masalah pendidikan warganya, pembagian peran dan tanggung jawab semacam ini menjadi adil. Pemerintah pusat memberi rambu-rambu dan dukungan teknis, pemerintah daerah membangun dirinya sesuai dengan potensinya sendiri. Jadi, sangat mungkin UN ini adalah salah satu strategi pemerintah pusat untuk lebih memacu pemberdayaan daerah dalam pendidikan warga negara, meskipun idealnya kegiatan semacam ini dilakukan oleh suatu badan independen penjamin mutu pendidikan.

Dengan demikian, UN adalah salah satu cara bimbingan dan pembinaan yang dilakukan pemerintah pusat pada daerah dengan cara memberikan shock therapy. Mestinya, pemerintah daerah dapat lebih memanfaatkan balikan dan merefleksikan hasil dari UN ini bukan malah menyikapinya secara negatif. Ibaratnya, pemerintah pusat dalam hal ini sedang memotret. Jadi bagus tidaknya objek pemotretan bukan semata-mata kesalahan si pemotret. Pemerintah pusat hanya mengungkapkan dan menunjukkan fakta keadaan daerah, pemerintah daerahlah yang akan menyikapinya. Apabila sudut pandang ini benar, maka UN bernilai positif. Namun, jika hal itu tidak benar, UN tidak jauh berbeda dengan kegiatan menginterogasi pesakitan tanpa ada hak jawab dan penjelasan dari si pesakitan. Dengan demikian, 
harapan, tantangan, dan peluang UN sebenarnya masih ada, dan UN mestinya dipandang dengan sikap positif dan optimisme untuk lebih memacu daerah agar lebih bergerak maju dalam koridor rambu-rambu pembangunan nasional, bukan sikap defensif tanpa dasar. Itu dilakukan sambil melakukan pembenahan teknis pada UN sebagai sistem pengujian.

\section{DAFTAR ACUAN}

Anderson, O. W. dan D. R. Krathwohl, Eeds. 2001 A Taxonomy for Learning, Teaching, and Assessing. New York: Addison Wesley Longman, Inc.

Athanasou, J. dan I. Lamprianou. 2002. A Teacher's Guide to Assesmen. Tuggerrah, NSW: Social Science Press.

Bachman, L. F. 1990. Fundamental Considerations in Language Testing. New York: Longman.

Fullan, M. 1982. The Meaning of Educational Change. New York: Teachers College Press, Columbia University.

Gunther, H. M. 2001. Leaders and Leadership in Education. London: Paul Chapman Publishing.

Husnawati, R. 2004. “Peningkatan Semu Mutu Pendidikan”. Jawa Pos, 6 Mei 2004.

Departemen Pendidikan Nasional. 2003. Ujian Akhir Nasional Tahun Ajaran 2003/2004.Keputusan Mendiknas Nomor 153/U/2003 Tanggal 14 Oktober. Jakarta: Departemen Pendidikan Nasional

Direktur Jenderal Pendidikan Dasar dan Menengah. 2004. “Memperbaiki Kelemahan Masa Lalu". Republika, Ahad, 30 Mei 2004.

Direktorat TK/SD. 1999. Nilai Ebtanas Murni SD/Ml Tahun 1999. Jakarta: Direktorat TK/SD Departemen Pendidikan Nasional.

Direktorat Pendidikan Lanjutan Pertama. 2004. Kebijakan Direktorat Pendidikan Pertama. Jakarta: Direktorat Jenderal Pendidikan Dasar dan Menengah, Departemen Pendidikan Nasional

Direktorat Pendidikan Lanjutan Pertama. 2001. Penilaian Berbasis Kelas. Jakarta: Direktorat Jenderal Pendidikan Dasar dan Menengah

Departemen Pendidikan Nasional Direktorat Jenderal Pendidikan Dasar dan Menengah. 2003. Undang-undang Republik Indonesia Nomor 20 Tahun 2003 tentang Sistem Pendidikan Nasional. Jakarta: Departemen Pendidikan Nasional

Forum Koordinasi Nasional Pendidikan untuk Semua. 2004. Kerangka Acuan Induk Kegiatan Pendidikan untuk Semua. Jakarta: Departemen Pendidikan Nasional.

Jawa Pos. 2004. “"DPR: Hapus UAN Tahun Depan"”. Edisi 5 Mei 2004.

Khomsan, A. 1995. "Permasalahan Pendidikan Dasar"“". Suara Karya, 18 April 1995.

Lewy, A. 1977. Handbook of Curriculum Evaluation. Paris: UNESCO.

Musthofa, Z.A. 2004. ""Berfikir Global Bertindak Lokal"”. Jawa Pos, 5 Mei 2004.

Nitko, J.A. 1996. Educational Assesmen of Students. Englewood Cliffs. New York: Merril, an Imprint of Prentice Hall.

Pedhazur, E.J. dan L.P. Schmelkin. 1991. Measurement, Design and Analysis. Hillsdale, New. York.: Lawrence Erlbaum Associates Publishers.

Prameswari, U. 2004. ““'Langkah Awal Majukan Pendidikan”.". Jawa Pos, 4 Mei 2004. Pujihastuti, U. 1995. "'Stagnasi Berfikir Kreatif dan Sistem Pendidikan Kita"”. Republika, Jum'at 7April 1995

Pusat Data dan Informasi Pendidikan. 2002. Statistik Persekolahan SD 2001/2002. Pusat Data dan Informasi Pendidikan. Balitbang, Depdiknas, 2002.

-------. Statistik Persekolahan SLTP 2001/2002. Pusat Data dan Informasi Pendidikan. Balitbang, Depdiknas, 2002.

-----. Proyeksi Pendidikan (TK, SLB, SD, SLTP, SM, PT, dan PLS) Tahun 2002/2003 - 2009/2010. Pusat Data dan Informasi Pendidikan. Balitbang, Depdiknas, 2003.

Pusisjian, 2003. Rata-rata NUAN SLTP Negeri/Swasta Tahun 2002/2003. Pusisjian, Depdiknas, 2003 
Santoso, S.H. 2004. "“UAN itu Perlu, tapi ..."”. Jawa Pos, 8 Mei 2004

Stiggins, R.J. 1994. Student-Centered Classroom Assesmen New York. New :Mcmillan College Publishing Company.

Supriyanto. 1995. "Guru, Kaum Muda, dan Masa Depan IPTEK". Pikiran Rakyat, 29 Januari 1995.

Sutejo. 1995. ""Guru dan Minusnya Kreatifitas"". Suara Karya, 23 Januari 1995.

Suyanto. 1995a. "'Guru Masa Depan Harus Paham Penelitian"." Surabaya Post, 25 Januari 1995

Suyanto. 1995b. "'Kendala bagi Guru SMA dalam Melaksanakan Kurikulum 1994" ".Kompas, 7 April 1995.

West-Burnham, J. 1997. Managing Quality in Schools $2^{\text {nd }}$ Edition: Effective Strategies for QualityBased School Improvement. London: Pearson Education.

Winoto, S. 2004. ““Transparansi Penyelenggaraan Pendidikan””. Jawa Pos, 14 April 2004. 